[ORIGINAL ARTICLE

Volume 16 Supp 12021

DOI: 10.21315/aos2021.16.51.3

ARTICLE INFO

Submitted: 02/03/2021

Accepted: 27/05/2021

Online: 22/09/2021

\section{Antibacterial Effectiveness of Calcium Hydroxide Combined with Cresotin against Enterococcus faecalis}

\author{
Aprilia $^{a^{*}}$, Belinda Kusuma ${ }^{b}$, Istien Wardani ${ }^{c}$ \\ ${ }^{a}$ Department of Conservative, Faculty of Dentistry, Universitas Hang \\ Tuah Surabaya, Kota Surabaya, Fawa Timur 60111, Indonesia \\ ${ }^{b}$ Faculty of Dentistry, Universitas Hang Tuah Surabaya, Kota Surabaya, \\ Jawa Timur 60111, Indonesia \\ ${ }^{c}$ Department of Pedodontic, Faculty of Dentistry, Universitas Hang Tuah \\ Surabaya, Kota Surabaya, FawaTimur 60111, Indonesia \\ *Corresponding author: aprilia@hangtuah.ac.id
}

To cite this article: Aprilia, Kusuma B, Wardani I (2021). Antibacterial effectiveness of calcium hydroxide combined with cresotin against Enterococcus faecalis. Arch Orofac Sci, 16(Supp.1): 11-15. https://doi.org/10.21315/aos2021.16.s1.3

To link to this article: https://doi.org/10.21315/aos2021.16.s1.3

\begin{abstract}
The goal of endodontic treatment is to prevent and control of pulp and periradicular infections. Calcium hydroxide has a beneficial biological property as an intracanal medicament and can be combined with cresotin to disinfect bacteria in root canals, especially Enterococcus faecalis (E. faecalis) which is the most frequently isolated strain in the root canals. The aim of this study was to investigate in vitro the antimicrobial activity of calcium hydroxide, cresotin, and combination calcium hydroxide and cresotin $\left(\mathrm{Ca}[\mathrm{OH}]_{2}+\right.$ Cresotin, $1: 1$ and 1:2) against E. faecalis. Antibacterial activity was determined by the agar diffusion method. The test medicaments were placed inside the hole that made in the inoculated agar medium. The zone of growth inhibition was measured and recorded after incubation for each plate, and the result was analysed statistically with ANOVA. The in vitro antimicrobial effects of combination calcium hydroxide and cresotin $\left(\mathrm{Ca}[\mathrm{OH}]_{2}+\right.$ Cresotin, 1:2) has more prominent antimicrobial activity than others, and calcium hydroxide is more effective than cresotin alone. The antimicrobial activity of combined calcium hydroxide and cresotin is more effective in killing $E$. faecalis in comparison to the other treatments.
\end{abstract}

Keywords: Calcium hydroxide; cresotin; endodontic treatment; Enterococcus faecalis

\section{INTRODUCTION}

Root canal infection is the result of colonisation of microorganisms, mainly dominated by anaerobic bacteria (Jaju \& Jaju, 2011). One of these bacteria is Enterococcus faecalis (E. faecalis) which is often isolated from root canal treatment cases. E. faecalis is a normal flora in the oral cavity, and this bacterium is often found $4 \%$ to $40 \%$ in primary endodontic infections (Mulyawati, 2011). The bacteria have the ability to survive in the unsupportive and malnourished environment, involves in the invasion of the dentinal tubules, suppress the action on lymphocytes, forms biofilms and resistant to calcium hydroxide (Athanassiadis et al., 2007; Fisher \& Phillips, 2009). 
Root canal treatment maintains teeth so that they last as long as possible and continue to function (Soedjono et al., 2009). The purpose of root canal treatment is to eliminate the bacteria that cause infections in the pulp tissue and periapexs (Sari \& Untara, 2014). The stages of root canal treatment contain root canal preparation which includes cleaning and forming of root canal framework (biomechanical), sterilisation and filling of the root canal (Soedjono et al., 2009).

In sterilisation stage, the aims are to eliminate microorganisms found in the root canals and dentinal tubules and also prevent contamination after treatment (Mulyawati, 2011). Sterilisation is very important to eliminate microorganisms that remain after the preparation and cleaning which can prevent recurrent infections in the root canal (Sari \& Untara, 2014).

Currently, the most commonly used sterilisation materials are calcium hydroxide $\left(\mathrm{Ca}[\mathrm{OH}]_{2}\right) \cdot \mathrm{Ca}(\mathrm{OH})_{2}$ has low water-soluble properties, has a high alkaline $\mathrm{pH}(\mathrm{pH} 12.5$ to 12.8), and is insoluble in alcohol. This low solubility of water makes $\mathrm{Ca}(\mathrm{OH})_{2}$ last a long time and can be absorbed by contact with vital tissues (Athanassiadis et al., 2007). $\mathrm{Ca}(\mathrm{OH})_{2}$ has an antimicrobial effect and the ability to neutralise toxins and bacterial products, so it is very effective to be used as a root canal sterilisation material (Kusuma, 2016). The antibacterial effect of $\mathrm{Ca}(\mathrm{OH})_{2}$ is influenced by the amount of $\mathrm{OH}$ - ions released. The alkaline environment, due to diffusion of $\mathrm{OH}$ ions causes lipopolysaccharide lipid hydrolysis of the bacteria, increases cell membrane permeability, protein denaturation, enzyme inactivation and DNA damage, resulting in bacterial death. The ability of $\mathrm{Ca}(\mathrm{OH})_{2}$ to indirectly absorb $\mathrm{CO}_{2}$ can also help the antimicrobial potential of both obligate and facultative anaerobic bacteria (Athanassiadis et al., 2007).
The tissues were strongly induced by alkaline from the $\mathrm{Ca}(\mathrm{OH})_{2}$ and calsium ions release (Kusuma, 2016). Cresotin contains phenol and formaldehyde which function as antiseptics. The mechanism of those materials is connected with the denaturation of microorganisms, causing antiseptic conditions and sterilisation of the root canals. Phenol and formaldehyde have acidic properties which release $\mathrm{H}+$ ions from their hydroxyl groups (Mărghitaş et al., 2011; Chandrashekhar \& Shashidhar, 2014). Phenol compounds can damage the cytoplasmic membrane, precipitate cell proteins, and damage cell membranes which cause leakage of important metabolites and inactivation of bacteria. Formaldehyde is a potent disinfectant and can react with proteins by forming methylene bridges that bind proteins to bacteria that damage the nucleus and cause protein coagulation in bacteria (Kohli, 2010).

In order to study the effectiveness of sterilisation materials, a combination of $\mathrm{Ca}(\mathrm{OH})_{2}$ and cresotin was evaluated. Both of those materials are potent as antimicrobial agents by denaturing microorganisms in the root canal (Verma et al., 2009; Dammaschke et al., 2013). By adding cresotin, it is expected that $\mathrm{Ca}(\mathrm{OH})_{2}$ can synergistically eliminate $E$. faecalis (Gulabivala \& $\mathrm{Ng}$, 2014). The combined materials were tested in vitro by the diffusion method to determine the inhibition of the combination against E. faecalis compared to $\mathrm{Ca}(\mathrm{OH})_{2}$ or cresotin itself.

\section{MATERIALS AND METHODS}

The materials used in this study were $\mathrm{Ca}(\mathrm{OH})_{2}$ and cresotin. The sample used in this study was the bacteria E. faecalis suspension which then was inoculated to brain heart infusion (BHI) agar media. The sample was divided into four groups namely, $\mathrm{P} 1=\mathrm{Ca}(\mathrm{OH})_{2}, \mathrm{P} 2=$ cresotin, P3 = combination of $\mathrm{Ca}(\mathrm{OH})_{2}$ : cresotin $(1: 1)$, $\mathrm{P} 4=$ combination of $\mathrm{Ca}(\mathrm{OH})_{2}$ : cresotin $(1: 2)$. 
The combination materials were made by mixing the two ingredients according to the ratio above the glass slab and stirred with sterile spatula. The method used in this study was the diffusion method and measurement of inhibition of $E$. faecalis using digital callipers.

\section{RESULTS}

The results of the study were analysed descriptively to get an overview of the distribution and summary of the data in order to clarify the presentation of research results.

P1 group produced an average inhibition zone of $9.54 \mathrm{~mm}$, the $\mathrm{P} 2$ group $(8.4 \mathrm{~mm})$, the $\mathrm{P} 3$ group $(11.49 \mathrm{~mm})$, and the $\mathrm{P} 4$ group $(13.53 \mathrm{~mm})$. P1 group $\left(\mathrm{Ca}[\mathrm{OH}]_{2}\right.$ only) has greater inhibition than the $\mathrm{P} 2$ group (cresotin only). The addition of cresotin (as shown in P3 and P4 groups) had increased the inhibition (Figs. 1 and 2).

It is known that the inhibitory results between the materials on the growth of E. faecalis were highest in the $\mathrm{P} 4$ group (Fig. 2). From the results of the research data, the normality test using the ShapiroWilk test showed normal data distribution. Additionally, by using the Levene test it is found that data on all groups had shown homogeneous variance. The parametric test using the one-way ANOVA was then conducted. Test results showed a significance value of $p=0.00$ and as $p<0.05$, it was concluded that there were significant differences.

\section{DISCUSSION}

The results showed that $\mathrm{Ca}(\mathrm{OH})_{2}$ has more significant inhibition than cresotin. This could be due to the physical structure of the sterilising material that was applied to the agar plate. $\mathrm{Ca}(\mathrm{OH})_{2}$ has a thick texture like a paste. Cresotin which was in liquid form would spread and evaporate and thus, do

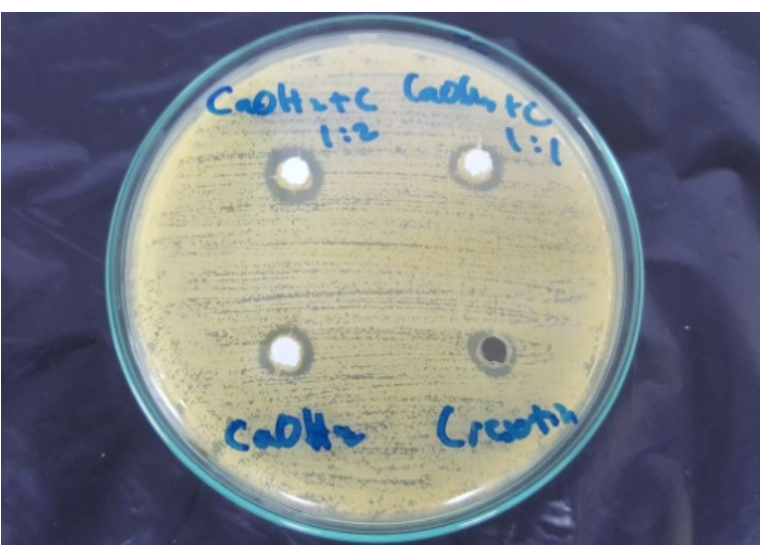

Fig. 1 The result of antibacterial activity against E. faecalis.

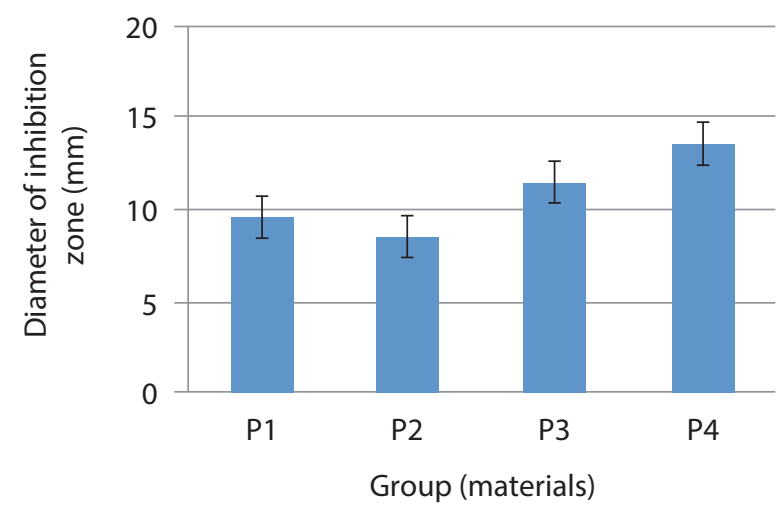

Fig. 2 The inhibitory results between the materials on the growth of E. faecalis.

not leave any residue on the plate. Similar conditions would happen during clinical settings where $\mathrm{Ca}(\mathrm{OH})_{2}$ is challenging to be cleaned in the root canal, while cresotin is easier using cotton pellets (Sari \& Untara 2014).

In the combination of $\mathrm{Ca}(\mathrm{OH})_{2}$ and cresotin group, the inhibition was more significant than the $\mathrm{Ca}(\mathrm{OH})_{2}$ group itself. This is probably due to the mixing of two ingredients with antibacterial properties. The release of hydroxyl ions from $\mathrm{Ca}(\mathrm{OH})_{2}$ can be accelerated or slowed down depending on the material that it was combined with. The faster the hydroxyl ion is released, the higher the number of bacteria were killed (Athanassiadis et al., 2007; Kim \& Kim, 2014). Cresotin which contains phenol and formaldehyde when combined with alkaline 
materials such as $\mathrm{Ca}(\mathrm{OH})_{2}$ will make the phenol and formaldehyde more reactive in releasing $\mathrm{H}+$ group, thereby increasing the antibacterial effectiveness (Madigan \& Martinko, 2006).

The P4 group (a combination of $\mathrm{Ca}(\mathrm{OH})_{2}$ :cresotin $\left.=1: 2\right)$ has a higher yield than P3 (a combination of $\mathrm{Ca}(\mathrm{OH})_{2}$ : cresotin $=1: 1)$ because the physical property of $\mathrm{P} 4$ paste were more watery and this maximised the spread of material on the plate. If this paste was applied to the root canal it works the same as how $\mathrm{Ca}(\mathrm{OH})_{2}$ acts, which directly contacted with the wall of root canal. Additionally, if the more reactive cresotin was mixed with alkali, more $\mathrm{H}+$ ions will be ionized and this helped to spread and disinfect the root canal up to the dentine tubules (Kim \& Kim, 2014).

\section{CONCLUSION}

The results of the study concurred with the hypothesis that there are differences in the inhibition between $\mathrm{Ca}(\mathrm{OH})_{2}$, cresotin and a combination of $\mathrm{Ca}(\mathrm{OH})_{2}$ and cresotin on the growth of $E$. faecalis. The result showed that the combination of $\mathrm{Ca}(\mathrm{OH})_{2}$ with cresotin was more effective in inhibiting the bacterium $E$. faecalis, thus can be considered as a root canal medicament drug choice.

\section{REFERENCES}

Athanassiadis B, Abbott PV, Walsh LJ (2007). The use of calcium hydroxide, antibiotics, and biocides as antimicrobial medicaments in endodontics. Aust Dent F, 52(Suppl 1): 64-82. https://doi.org/10 $.1111 / j .1834-7819.2007 . t b 00527 . x$

Chandrashekhar S, Shashidhar J (2014). Formocresol, still a controversial material for pulpotomy: A critical literature review. f Res Dent, 2(3): 114-124. https://doi.org/ 10.4103/2321-4619.143594
Dammaschke T, Jung N, Harks I, Schafer E (2013). The effect of different root canal medicaments on the elimination of Enterococcus faecalis ex vivo. Eur $\mathcal{f}$ Dent, 7(4): 442-448. https://doi.org/10.4103/1305 $-7456.120683$

Fisher K, Phillips C (2009). The ecology, epidemiology and virulence of Enterococcus. Microbiology, $155(\mathrm{Pt}$ 6): 1749-1757. https://doi.org/10.1099/mic $.0 .026385-0$

Gulabivala K, Ng YL (2014). Endodontics, 4th edn. St Louis: Mosby Elsevier, pp. 80-85.

Jaju S, Jaju PP (2011). Newer root canal irrigants in horizon: A review. Int $\mathcal{F}$ Dent, 2011: 851359. https://doi.org/10 $.1155 / 2011 / 851359$

Kim D, Kim E (2014). Antimicrobial effect of calcium hydroxide as an intracanal medicament in root canal treatment: A literature review - Part I. In vitro studies. Restor Dent Endod, 39(4): 241-252. https://doi.org/10.5395/rde.2014.39.4.241

Kohli A (ed.) (2010). Textbook of Endodontics, 1st edn. Haryana: Elsevier India, pp. 154.

Kusuma ARP (2016). Pengaruh lama aplikasi dan jenis bahan pencampur serbuk kalsium hidroksida terhadap kekerasan mikro dentin saluran akar. Odonto Dent f, 3(1): 48-54. https://doi.org/10.30659/odj.3.1.48-54

Madigan MT, Martinko JM (2006). Brock Biology of Microorganisms, 11th edn. Glenview: Pearson Prentice Hall, pp. 753-755.

Mărghitaş L, Dezmirean D, Chirilă F, Fiţ N, Bobiș O (2011). Antibacterial activity of different plant extracts and phenolic phytochemicals tested on paenibacillus larvae bacteria. Sci Paper Anim Sci Biotechnol, 44(2): 94-99. 
Mulyawati E (2011). Peran bahan desinfeksi pada perawatan saluran akar. Maj Kedokt Gigi Indones, 18(2): 205-209. https://doi.org/10 $.22146 /$ majkedgiind. 15427

Sari AN, Untara TE (2014). Root canal retreatment menggunakan kombinasi kalsium hidroksida dan chlorhexidine sebagai medikamen intra kanal insisivus sentral kiri maksila. Maj Kedokt Gigi Indones, 21(2): 165-170. https://doi.org/ 10.22146/majkedgiind.8752
Soedjono P, Mooduto L, Setyowati L (2009). Penutupan apeks pada pengisian saluran akar dengan bahan kalsium oksida lebih baik dibanding kalsium hidroksida. f Persatu Dokt Gigi Indones, 58(2): 1-5.

Verma P, Chandra A, Yadav R (2009). Endodontic emergencies: Your medication may be the cause. $\mathcal{F}$ Conserv Dent, 12(2): 77-79. https://doi.org/10.4103/0972-0707 .55623 